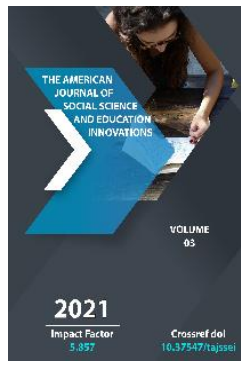

Journal Website: https://theamericanjou rnals.com/index.php/ta jssei

Copyright: Original content from this work may be used under the terms of the creative commons attributes 4.0 licence.

\section{Improvement Of Organizational And Economic Mechanisms Of Organization Of Vine Clusters}

\author{
Bahodir Ibragimovich Isroilov \\ Doctor Of Economical Sciences, Professor, Department Of "Financial Analysis And Auditing", \\ Tashkent State University Of Economics, Uzbekistan \\ Ilhom Sayitkulovich Ochilov \\ Candidate Of Economical Sciences, Doctoral Candidate, Tashkent State University Of \\ Economics, Uzbekistan
}

\title{
ABSTRACT
}

The article analyzes the role and importance of cluster structures in the development of the agricultural sector and foreign experience in organizing their activities. The authors also assessed the organizational mechanisms of agro-clusters and their role in improving the efficiency of cluster performance. As a result of the research, recommendations have been developed to improve the organizational and economic mechanisms of agro-clusters in Uzbekistan.

\section{KEYWORDS}

Cluster, agro-cluster, efficiency, viticulture, economic, financial, modern, technology, innovation, intensive, export, import, product.

\section{INTRODUCTION}

An innovation-based economy is being formed by countries around the world. In developed countries, cluster structures are important in the development of the agricultural sector. In recent years, the Republic of Uzbekistan also considers the provision of the domestic market with quality products by increasing food production and increasing the country's export potential as a priority. As a result of measures taken to reform the agricultural sector in 20152020, more than 80 types of agricultural products are exported to 66 countries. In 2010, cotton fiber accounted for $11.3 \%$ of exports, but by 2018 this figure had dropped to $1.6 \%$ [1].Uzbekistan is one of the countries with historical experience in agricultural production and climatic conditions with the potential to double the yield of land. However, as a result 
of shortcomings in the use of modern mechanisms in the proper organization of production, the existing opportunities in the industry are not fully used.

As noted in the Strategy for the Development of Agriculture of the Republic of Uzbekistan until 2030, effective mechanisms for uniting small agricultural producers are not fully formed, so they are scattered. The low level of achievement of high economic performance due to the slow implementation of advanced organizational structures in the industry limits the possibility of integration of the production cycle into value chains. The share of cooperatives in the markets of developed countries (European Union, USA, Canada) exceeds $40 \%$, and in Uzbekistan this trend is still developing [2].

Also, in the viticulture sector, which is an important area of the agricultural sector, there is a lack of systematic specialization in accordance with climatic conditions, effective market mechanisms in the development of producers, processors, trade, export and logistics structures and viticulture; the inadequacy of the scientific approach is leading to the underutilization of the existing capacity of the network. Calculations show that there is an opportunity to earn 7 times more from grapes, 6 times more from cherries, 5 times more from walnuts than from raw cotton grown on 1 hectare.

Therefore, we believe that the establishment and operation of clusters of viticulture and winemaking, which are important exportoriented areas of agriculture, will contribute to the sustainable development of the Uzbek economy and the continuity of the value chain and increase the country's export potential.
THE MAIN FINDINGS AND RESULTS

Along with the term "cluster", the term "clustering" is used in the economy. Clustering (cluster analysis) is the process of dividing a set of objects into groups called clusters. This means that there are "similar" objects within each group, and that the objects in different groups are as different as possible. Depending on the structure, size and type of activity, the principles of cluster formation are divided into principles that represent the purpose, form and content, management and interaction. At the same time, the goal principles formed on the basis of the interests of the participants lead the proposed system of cluster formation. In turn, the principle of cluster formation should be based on the principles of its operation, economic, organizational, technological and structural nature, which will ensure the balanced (adequate) development of all participants in the cluster and the cluster itself. A cluster involves the continuous improvement of all its elements, and their interconnection contributes to the competitiveness of both the individual element and the whole cluster [3].

The development of clusters coincided with Western Europe, the United States, and the United Kingdom in the mid-twentieth century. The cluster approach became the basis of the economies of countries such as Finland, South Korea and Brazil in the 1990s. It is noted that the interest in clustering is growing not only in government, but also in the field of research. It is recognized that as a result of clustering economies, developed (US, UK, Denmark, France, Finland), developing (China, India, Indonesia, Mexico) and transition economies (Hungary, Slovenia, Kazakhstan, Ukraine) countries have achieved economic growth [4].

The agricultural sector is not only a sector that meets the demand of the population for food products, but also a supplier of local raw materials that are important for other sectors 
of the economy and serves to create value added. As a result of reforms to diversify the economy in Uzbekistan, the level of the share of agriculture in the country's GDP has changed compared to the early years of independence. Prior to independence, Uzbekistan was the raw material base of the former Soviet Union, and processing of its products was carried out in other republics. The share of Uzbekistan in the added value created as a result of nonapplication of the cooperative method of production is not taken into account and is included in the system of the country, which receives subsidies from the republic. Prior to independence, "the share of finished products in industry was only 50 percent, and more than 80 percent of agricultural products were exported without any processing. The fact that two-thirds of the products exported from the republic are raw materials and semi-finished products indicates the deep imbalances in the structure of social production. About $60 \%$ of the goods imported to the country are machinery, equipment, light industry and food industry" [5].

As a result of reforms implemented during the years of independence to diversify the economy and regulate the processing of raw materials, there are now positive changes in the composition of GDP and efficiency indicators (Diagram 1).

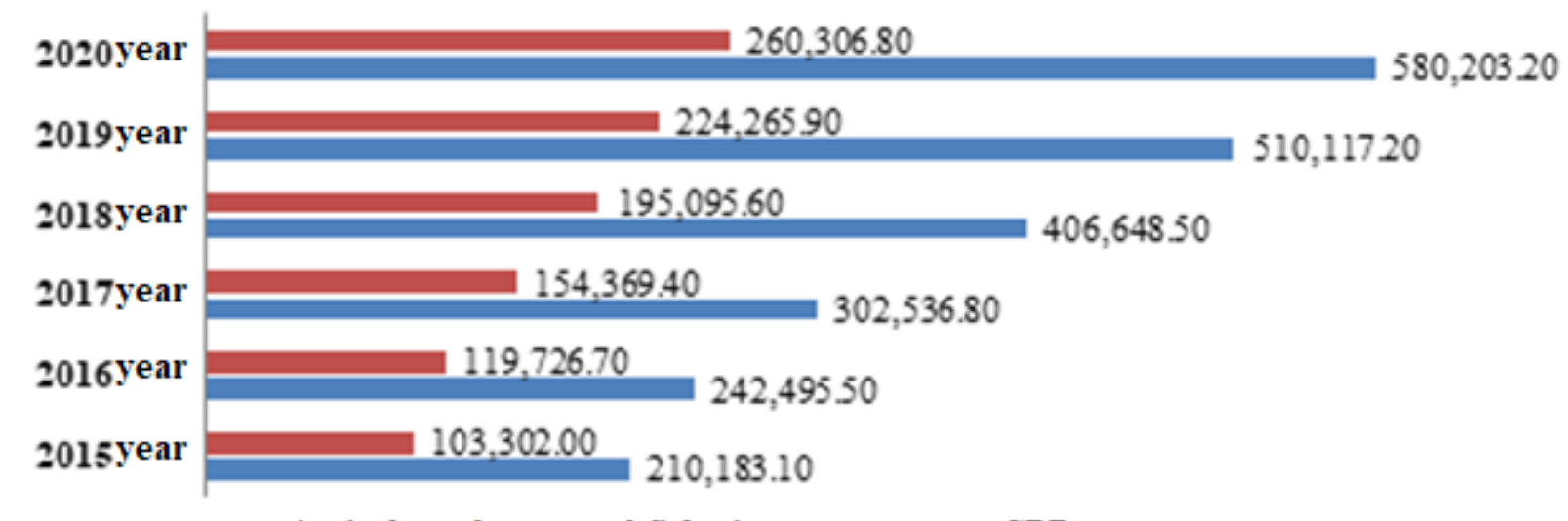

Agriculture, forestry and fisheries

GDP

\section{1-Diagram. Analysis of changes in the dynamics of agricultural production in the GDP of the Republic of Uzbekistan (billion soums) (Development of authors on the basis of data of the State Statistics Committee of the Republic of Uzbekistan)}

As a result of the introduction of the system of processing of agricultural products, the share of agricultural products in GDP in 2020 decreased by $4.8 \%$ compared to 2015 , respectively, the share of industrial production increased by $16.8 \%$. In addition, in 2015, agricultural products worth 99604.6 billion soums were grown on 3694.2 hectares of land, and by 2020, 249754.5 billion soums were harvested on 3373.1 hectares of land [6]. However, despite the structural changes that have taken place and the increase in production efficiency, the value chain system for products grown in the agricultural sector is still not fully formed.

As a result of the study of the problems of agricultural development, B. Johnston and J. Mellor conclude that the development of consumer and production relations between the sectors of the agricultural economy has a significant impact on the economic development of the country [7]. 
It is recognized in the literature that the organization of cluster activities has the following objectives [8-11]:

- Increase the competitiveness of cluster members through the introduction of new technologies;

- To achieve drastic changes in the development of technology;

- Commercialization of existing knowledge;

- To increase the efficiency of scientific services as a result of energy activities;

- To increase the level of knowledge development. view, clusters are divided into geographical, network, horizontal and vertical categories. Analysis of foreign experience shows that the application of the principles of the model "Triple Helix" in the development of organizational mechanisms of clusters gives a positive result. The "Trinity Spiral" model was developed in the 21st century in England and the Netherlands by Henry Itskovitz, a professor at the University of Newcastle, and Loyette Leidesdorf, a professor at the University of Amsterdam. The content of the model is based on the interaction of "government", "business" and "educational institution" (Figure 1).

As a result of research on foreign experience in the organization of clusters and the specifics of their activities, from an organizational point of

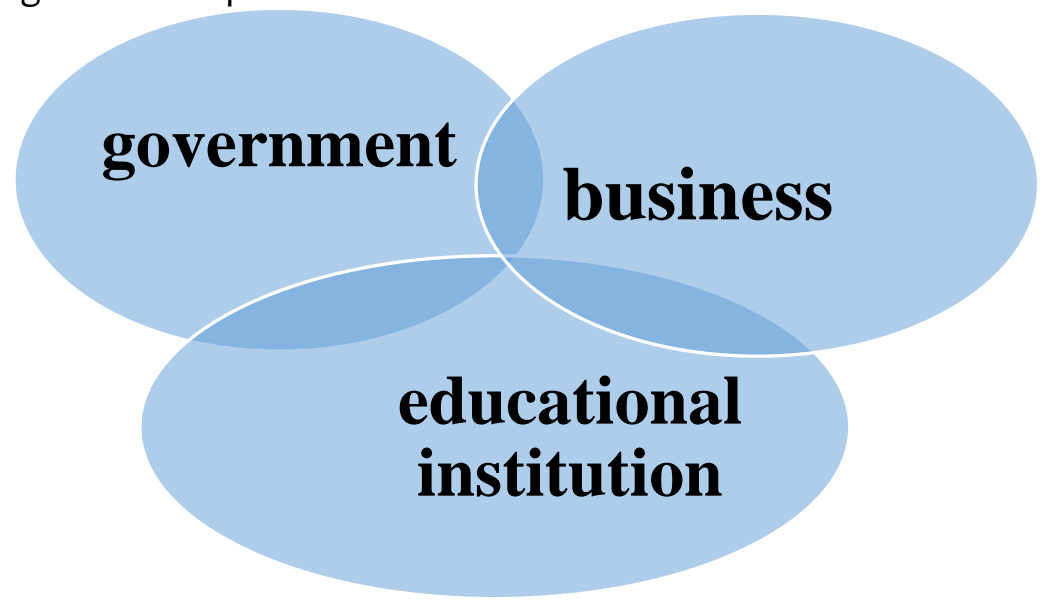

Figure 1 The content of the model of the organization of clusters "Triple Spiral". (Henry Itskovits, prepared by the authors based on the idea of Loyette Leidesdorf)

In the organization of clusters, the model of the "Triple Spiral" recognizes that the result is positive when the activities of the structures are organized on the principles of interest, initiative, negotiation, agreement and cooperation. However, the principles of this model are not taken into account in the formation of clusters in Uzbekistan. The state takes the initiative in organizing clusters, determines the composition of participants and economic mechanisms of operation. In the practice of Uzbekistan, the establishment of clusters by the state has led to the establishment of all organizational and economic mechanisms, as well as a violation of the principles of the "triple spiral" model. For example, Art Naman Soft Holding LLC (agroindustrial cluster), established by the government in Namangan region, does not have any cotton-growing farmers, dehkan farms, logistics companies and other service providers. On the contrary, the decision obliges the society as a parent company to create new enterprises that are part of the agro-cluster and provides a number of benefits to the agrocluster. 
The application of cluster technologies in the agricultural sector is a tried and tested approach of foreign experience to serve economic growth. This is evident from winemaking in California, wine and cognac in France, milk production in Denmark, glaze production in Switzerland, and grain clusters in Canada and the United States. The positive results of the application of cluster technologies by developed countries in specific areas of the agricultural sector, the use of which will serve to develop the industry and the economy in our country.

The experience of foreign countries shows that economic growth and development in industries through the use of public-private partnerships in the activities of clusters as an organizational mechanism. In Colombia, for example, flower clusters are set up by local and international investors, and in part by the government, and as a result, the country begins to export non-traditional flowers. The flower cluster in Ecuador and the apple cluster in Santa Catarina (Brazil) have also developed in a public-private partnership. Also, the basic principle of clustering in foreign practice is aimed at strengthening coordination between local agricultural enterprises and the public sector, research institutes and research institutions.

\section{RESULTS AND DISCUSSIONS}

The analysis of foreign experience of clustering shows that in its organization it is necessary to take into account the economic development and geographical location of the country. For example, Latin American viticulture clusters have traditionally been formed by many small winemakers and family wineries that produce and wholesale wine in the domestic market. They accounted for a very small portion of the country's wine export production in the 1970s and 1980s. In the 1990s, producers shifted from producing wine for the domestic market to producing high-quality wines for high-demand export markets. As a result, $99 \%$ of the wine industry's export earnings came from wine exports in Bolivia, Brazil, and 98\% in Uruguay, 85\% in Argentina and 41\% in Chile. In 1998-2000, Latin American countries invested between \$ 500 million and $\$ 600$ million directly to form viticulture clusters. Foreign investors have invested in the use of indoor crops, increasing the planting density of vines, creating new varieties, drip irrigation, as well as French, California and Australian winemaking technologies in the basement.

Also, new methods of management and marketing were adopted in the viticulture cluster: modern product production, quality control processes, design and joint benchmark (development of new systems for documenting practice and products, data exchange and evaluation of results in time and space). and led to an increase in the production of export-oriented products.

In the context of the COVID-19 pandemic in 2020, along with other industries, the wine industry in the world has experienced an economic downturn compared to previous years. Wine was exported worldwide for 29.6 billion euros, a decrease of $6.7 \%$ compared to the same period last year.

In particular, in Latin America, Chile's wine exports amounted to 8.5 million hectoliters in 2020, down 2\% from 2019, while Argentina exported 4.0 million hectoliters of wine in 2020. In terms of export value, it amounted to 1595 thousand Euros (-7.1\% / 2019) in Chile, and 655 thousand Euros (-4.0\% / 2019) in Argentina.

Analysis of the development trends of viticulture clusters in Latin American countries shows that the factors for achieving high efficiency are as follows:

- Creation of an attractive environment for investment in this sector with the improvement of macroeconomic conditions, including trade and tax policy;

- Attracting foreign investors to the industry who are well versed in modern methods of winemaking, marketing and management; 
- The emergence of collective action of stakeholders;

- Institutional support of wine clusters by government agencies, universities, research institutions, etc.

At the same time, if we look at the analysis of the organizational and economic efficiency of viticulture clusters, we can see more of the more influential aspects of economic factors. In terms of state support, state support for the development of wine clusters in Chile and Argentina has been important. The government provided them with institutional assistance in three ways:

- By liberalizing the production and export of grapes and wine;

- Support for the study of technologies for export, especially for small producers;

- Support of export promotion measures and collective marketing initiatives.

In addition, the government has paid great attention to the collection of information on changes in the market and the rapid resolution of problems related to the coordination of small and medium enterprises.

Uzbekistan has a great potential for the cultivation of grapes, its processing and production of finished products, as well as the development of wine tourism (Enotourism). Therefore, measures have been developed to develop this sector. At present, a continuous system will be created in the regions to specialize in the cultivation of grapes in 48 districts and to establish vineyards on 156,000 hectares and deliver them to consumers. Establishment of grape and wine clusters from September 1, 2021 to create a full cycle of grape growing, drying, packaging, processing, production and export of finished products, to stimulate the production of natural wine from locally produced grapes and berries. From January 1, 2021, an excise tax of 1 soum was introduced for 1 bottle of sparkling wine [14].

The purpose of using the cluster method in the agricultural sector is to increase the efficiency of their activities and ensure the continuity of the value chain mechanism. However, despite the fact that clustering began 3-4 years ago, the role of "educational institution" in their activities is still not felt. The education sector needs to innovate the clusters and ensure the economic development of the sector. As noted above, while the principles are taken into account in the organization of clusters, the application of the structure of the model "Triple Spiral" is also neglected.

\section{CONCLUSION}

Development of the industry on the basis of the analysis of foreign experience in the organization of viticulture clusters in our country will serve to achieve the following positive results:

- Clustering of viticulture and wine industry will provide industrialization of the industry, acceleration of innovation and modernization processes, attraction of foreign investment, active dialogue between the public and private sectors, increase the competitiveness of agroindustrial sectors, encourage producers;

- Farmers and small and medium-sized agribusinesses will benefit from participation in the cluster, the development of cluster policy in accordance with the requirements of the "Triple Spiral" model will allow to achieve cost-effectiveness, information exchange, certification and effective organization of technology-related activities;

- Clustering initiatives should be coordinated on the basis of the principle of interest between the state, business, scientific institutions, financial intermediation institutions or other organizations;

- Direct investments serve as a financial source for economic growth of the sector and the attraction of knowledge and technology, so it is necessary to take measures to increase the attractiveness of investment in the agricultural sector; 
- Cooperation between academic and research institutions in the development of clusters to achieve targeted orientation of scientific and educational programs in areas beneficial to the cluster;

- Investing in private sector research to develop clusters, disseminate technological innovations and increase incentives to provide technical assistance to the primary sector;

- In order to quickly solve the problems in the industry, it is expedient to increase financial opportunities for investment, control food security, establish fair competition, strengthen environmental standards, develop legal norms to address energy and water issues.

\section{REFERENCES}

1. Resolution of the President of the Republic of Uzbekistan dated December 11, 2019 No PD-4549 "On additional measures for further development of the fruit and vegetable and viticulture sector, the creation of a value chain in the industry".

2. Decree of the President of the Republic of Uzbekistan dated October 23, 2019 No PD5853 on approval of the "Strategy of agricultural development of the Republic of Uzbekistan for 2020-2030".

3. Tereshin E.M. Volodin V.M. (2011) The principles of cluster associations in the Russian economy. Economy of agricultural and processing enterprises. No 3. - pp. 5760.

4. Frolova O.A. Agro-industrial clusters: the Russian model. Bulletin of NGIEI https://cyberleninka.ru/article/n/agropro myshlennye-klastery rossiyskaya-model.

5. I.A.Karimov. (2011) Uzbekistan on the threshold of independence. I.A. Karimov. - Tashkent. "Uzbekistan". - p. 440.

6. https://www.stat.uz

7. Johnston, B. F., J. W. Mellor. The Role of Agriculture in Economic Development. //
The American Economic Review 51 (4), 1961, pp. $566-593$.

8. Kazavatova, N. Yu. Clusters in the agroindustrial complex: theory, problems and prospects [Electronic resource]. N. Yu. Kazavatova, RI Yarakhmedov. Management of economic systems. - 2012. No. 10 (46).

9. Itskovitz H. (2000) Dynamics of innovation: from national systems and "mode 2 " to the triple helix of the university -Industry - relations with the government / H. Itzkowitz, L. Leidesdorf // J. Research Policy. No 29. - pp. 109-123.

10. Alekseev V.P. (2012) System analysis and methods of scientific and technical creativity. scientific and technical creativity]. V.P. Alekseev, D.V. Ozerkin. Tomsk. TUSUR. - p. 183.

11. Suslova T.I. (2012) A man in the world is a world in a man. T.I. Suslova E.M. Pokrovskaya, M.Yu. Raitin. - Tomsk: TUSUR. - p. 162.

12. FAO. 2008. Grape Exports with GLOBALGAP Certification: Case Study of Mahindra \& Mahindra Initiative in India (Draft). Available at: http://www.fao.org/world/regional/rap/ag roindustries/Mahindra\%20GLOBALGAP\%20 Grape\%20Export.pdf

13. https://www.oiv.int/public/medias/7909/o iv-state-of-the-world vitiviniculturalsector-in-2020.pdf

14. Resolution of the President of the Republic of Uzbekistan dated July 28, 2021 No PD-5200 "On the introduction of a cluster system in the development of viticulture, additional measures of state support for the involvement of advanced technologies in the industry. 